\title{
A resposta do homem e de Deus: a existência
}

\author{
The answer of man and God: the existence
}

\author{
JOÃO EDUARDO LAMIM ${ }^{1}$
}

Resumo: Diante de uma construção histórica, as atitudes humanas acabaram por formar uma realidade distorcida e construída sob falsos valores éticos, ainda presentes na contemporaneidade. $\mathrm{O}$ maior expoente de tal crise é o antropocentrismo, refletido na exploração irresponsável da Terra e nas relações éticas e humanas esfaceladas. O ser humano tem um intransferível papel diante desta realidade que ele mesmo construiu: pelo amor sustentável à vida e suas manifestações é convocado a reconstruir as relações humanas com a Terra baseado na reverência, respeito e, sobretudo, cuidado com a criação. O cuidado apresenta-se como imperativo ético necessário para o restabelecimento da relação entre Terra e ser humano; este deve ser o protagonista desta mudança através de uma conversão radical de mente e coração, a fim de que suas atitudes sejam críticas, criativas e sustentáveis. Uma mudança no âmbito existencial seria a marca decisiva para a construção de uma nova era planetária, marcada pelo respeito e cuidado pela vida, força que anima toda a realidade, inclusive a Terra, sinal por excelência da vida e da fecundidade. Tal resposta, crítica, criativa e concreta, abre-se à integralidade da vida, estendendo o cuidado a todas as dimensões de vida, relacionamentos, compreensões e dinâmicas. Todo o corpo, sentimentos, toda a espiritualidade e pensamentos devem estar permeados de cuidado e transcendência, buscando verdadeiro sentido e força vital de/para existir.

Palavras-chave: Terra. Ética. Existencialismo. Espiritualidade. Cuidado.

Abstract: In front of a historical construction, the human attitudes arrived at forming a distorted reality, constructed upon false ethical values, still present in the contemporary world. The bigger exponent of this crisis is anthropocentrism, reflected in the irresponsible exploitation of the earth and in the ethic and human relations broken down. The human being has an untransferable role towards this reality that he himself produced: through the sustainable love to life and its manifestations, he is called to reconstruct the human relations with the earth based upon the reverence, respect and, overall, care with the creation. The care presents itself as an ethic imperative necessary for the reestablishment of the relation between Earth and human being; this has to be the protagonist of this changing through aradical conversion of mind and heart, in order that his attitudes be critic, creative and sustainable. A change in the existential ambit would be the decisive mark for the construction of a new planetary age, marked by the respect and care for the life, force that animates the whole of reality, Earth included, the most excellent sign of live and fecundity. Such an answer, critic, creative and concrete, opens itself to the integrality of life, extending care to all dimensions of live, relations, comprehensions and dynamics. The whole of the body, sentiments, spirituality and thought have to be permeated of care and transcendence, looking for the true meaning and vital force of the existence.

Keywords: Earth. Ethics. Existentialism. Spirituality. Care.

\footnotetext{
${ }^{1}$ Graduando de Teologia na Faculdade Católica de Santa Catarina, em Florianópolis/SC; Bacharel em Filosofia, Faculdade São Luiz, Brusque - SC, 2012, com a monografia "O existir como resposta à crise ético-ambiental em Leonardo Boff", orientada pelo Prof. Dr. Marcio Bartel (Graduado em Direito, Filosofia e Teologia. Pós-graduado em Direito e Processo do Trabalho. Pós-graduado em Educação. Mestrado em Filosofia pela Universidade Católica de Louvain, Bélgica. Doutorado em Filosofia pela Universidade Católica de Paris com tese sobre "A ideia de Justiça na ética de Paul Ricoeur". Professor na Estácio de Sá. Advogado. Avaliador de Cursos e de Instituição do MEC). E-mail: joaoedursl@gmail.com
} 


\section{Introdução}

Quando paramos e lançamos um olhar reflexivo sobre a realidade, percebemos que, no seu processo histórico, ela sofreu inúmeras mudanças. O mundo em que vivemos, entendido como a Casa Comum da raça humana, está em constante mudança: mudança de pensamento, de organização social e política, mudança no modo de vestir, de se comportar, de hábitos, costumes, mudança na maneira de pensar-se como ser humano religioso e cultural, mudança de formas de relacionamento, em especial na relação com a Terra e seus ecossistemas. A Terra todos os dias se renova, refaz e reanima os seres que nela habitam com uma força originária, a força da vida, que permeia todas as dimensões possíveis. A vida, presente em tudo, faz com que tudo se transforme continuamente, e funcione de modo relacionado, ou seja, que um dependa do outro para continuar a existir e se renovar. Estamos num tempo de mudança e aparente crise com as relações naturais. O ser humano tem um papel fundamental para a transformação holística e integral da realidade. Estamos instalados, enquanto raça humana, num único e mesmo planeta, e ainda convivemos com outras tantas formas de vida (animais irracionais, plantas, bactérias, seres microscópicos, etc). Porém algumas características humanas negativas, fruto de uma maneira de pensar coletiva, fez com que essa convivência terrenal fosse distorcida de seu sentido essencial. Tais características, como o antropocentrismo, a maneira de pensar o trabalho como meio exclusivo para o desenvolvimento lucrativo por meio da exploração das forças dos trabalhadores, o modo de viver e de pensar o consumo como arrecadação e aquisição de bens para o uso de poucos, tornando o homem escravo do consumo e do descarte instantâneo do que não mais lhe agrada ou convém, a exploração e utilização irresponsável dos bens naturais, faz com que nos coloquemos diante de uma realidade em crise. A crise na qual estamos inseridos centra-se na inversão dos valores para uma convivência autêntica entre o ser humano e os ecossistemas da Terra. Quando centrado na vontade humana, a relação desequilibra-se, já que facilmente procuramos privilegiar a vontade individual sobre a coletiva. Assim, só se pode reverter este quadro de crise ecológica pela dimensão existencial do próprio ser humano. Apenas uma mudança radical de atitude, de uma maneira de existir moralmente autêntica, fará que a crise possa reverter-se em um novo caminho a ser trilhado. Tudo que presenciamos atualmente quanto aos desastres naturais é reflexo do desequilíbrio em que se encontra a Terra devido a exploração irresponsável que sofreu durante anos. Nós seres humanos, que encaminhamos a Terra para este estado, somos os responsáveis por tirá-la deste dilema, e fazê-la encontrar seu equilíbrio novamente. A filosofia e a teologia, com o método crítico-reflexivo e espiritual de pensar e agir, torna-se uma base sólida para que busquemos o equilíbrio dos ecossistemas da Terra e das relações internas por ela. Através de princípios pensados, refletidos e assumidos conjuntamente, poderemos fazer surgir no horizonte novas perspectivas de ação e de vida, onde a própria existência humana seja renovada. Por princípios e atitudes 
concretas o homem pode transformar a realidade em que está. Se a Terra sofre e apresenta sinais de morte, o homem tem o poder e a responsabilidade de criar uma nova era planetária: do cuidado com a vida, do amor pelo próximo, da responsabilidade social e da cooperação mútua. Tais valores surgem de uma profunda reflexão filosófica, para tomar consciência da realidade complexa, e da experiência interior/religiosa, para ganhar coragem e força no caminho da restauração.

\section{Ecologia: conhecimento da própria Casa}

A proposta de um desenvolvimento sustentável já é antiga, porém permanece sempre atual como saída para uma vivência digna e autêntica que o ser humano pode dar diante da realidade em que está situado. Quando se fala em sustentabilidade, pensa-se logo na dimensão ecológica, como meio de relação homem-natureza. Porém ela é mais ampla e envolve outras tantas realidades humanas. Félix Guatarri nos ajuda a entender o verdadeiro entendimento de ecologia e abre nosso horizonte explicitando as suas famosas três ecologias (cf. GUATTARI, 1988):

[...] a ambiental, que se ocupa com o meio ambiente e as relações que as várias sociedades históricas entretêm com ele, ora benevolentes, ora agressivas, ora integrando o ser humano na natureza, ora distanciando-se dele; a social, que se ocupa principalmente com as relações sociais como pertencentes às relações ecológicas, pois o ser humano pessoal e social é parte do todo natural e a relação para com a natureza passa pela relação social de exploração, de colaboração ou de respeito [...]; por fim, a mental, que parte da constatação de que a natureza não é exterior ao ser humano, mas interior, na mente, sob forma de energias psíquicas, símbolos, arquétipos e padrões de comportamento que concretizam atitudes de agressão ou de respeito e acolhida da natureza (BOFF, 1995, p. 86 [grifos do autor].

Perante tal compreensão de ecologia integral, constatamos atualmente uma forte e imperante crise de valores. A vida é a força fundante que anima todas as coisas e lhes dá sentido para existir e coexistir. Ela é o princípio do qual todas as coisas animadas dependem para viver. Assim, é papel do ser humano ser responsável pela vida presente em todas as coisas e dimensões. ${ }^{2}$

Precisamos, enquanto seres racionais, preservar, guardar e cuidar da vida, e garantir vitalidade e dinamismo ás relações básicas que estabelecemos, seja no meio social, cultural, econômico e ambiental. Em contraponto, o que mais presenciamos até agora tem sido justamente o contrário.

\footnotetext{
${ }^{2}$ Tal pensamento é inspirado na concepção vitalista da realidade, que explica as realidades terrestres como animadas por uma força, um impulso fundamental que, atuando sobre a matéria, dá a possibilidade da existência, da vida. Esta força de vida torna-se assim um princípio que deve ser respeitado e zelado para que a vida seja um bem para todos sem limitação de espaço ou tempo. [cf. SPECULUM. Vitalismo. Disponível em: <http://www.filoinfo.bemvindo.net/filosofia/modules/lexico/entry.php?entryID=1097>. Acesso em: 02 abr. 2012].
} 
"Não existem relações humanas que não sejam permeadas por algum tipo de ética, entendida como conjunto de valores e critérios que servem para dar a toda ação uma conotação de 'boa' ou 'má”' (ARRUDA, 200oa. p. 35). Podemos, logo, afirmar que a crise que percebemos hoje provém de uma deficiência de valores éticos que garantam tal conotação boa necessária. Mas em que falha a raça humana?

O problema [...] não é "falta de ética" nas relações internacionais que configuram uma ordem global marcada pela desigualdade e pela injustiça, mas sim uma ética centrada em falsos valores, apegada apenas aos interesses ligados à riqueza, ao prestígio e ao poder, ou restrita às peripécias superficiais da História contemporânea. Uma ética cega, portanto, à realidade mais profunda e abrangente de um ser humano que é ao mesmo tempo indivíduo e sociedade, ponto culminante da onda evolutiva da natureza e um ser sempre em construção, cuja estrutura e dinâmica física, cultural e psíquica continuam evoluindo num tempo unitário e irreversível [grifos do autor] (ARRUDA, 2000a. p. 35).

Identificando a origem do problema ético atual, podemos nos propor a reverter as dores da crise em esperança do nascimento de uma nova consciência ética.

\subsection{Tecnologia, sociedade, e o homem}

Quando falamos na crise que atinge o século presente, em especial na dimensão ecológica da Terra, logo nos urge a necessidade de medidas para devolvermos à vida sua originária eficácia. Mas precisamos encontrar o fundamento de tal crise, para podermos aplicar o remédio na raiz do problema, e então tentar reverter o quadro de crise em crescimento e desenvolvimento autêntico.

A sociedade contemporânea, chamada sociedade do conhecimento e
da comunicação, está criando, contraditoriamente, cada vez mais
incomunicação e solidão entre as pessoas. A Internet pode conectar-
nos com milhões de pessoas sem precisarmos encontrar alguém.
Pode-se comprar, pagar contas, trabalhar, pedir comida, assistir a um
filme sem falar com ninguém. Para viajar, conhecer países, visitar
pinacotecas não precisamos sair de casa. Tudo vem à nossa casa via
on line (BOFF, 1999, p. 11).

A tecnologia, ícone principal da formação da sociedade atual, fornece-nos o exemplo mais significativo do fundamento ético destes nossos tempos: o imediatismo, caracterizado pela prontidão e imediata difusão da informação no mundo digital, e por consequência ao ser humano a contradição, que ao mesmo tempo interliga e isola pessoas.

O sistema eletrônico de comunicação pode ajudar e facilitar a integração das pessoas, porém por outro lado pode representar também um grande risco para a geração atual. Ao mesmo tempo em que se pode conectar e interagir virtualmente com muita gente, acaba por degenerar a relação afetiva com as pessoas. Não é difícil 
vermos jovens que são um fenômeno na internet, que mantêm grande rede de relacionamentos virtuais, porém não conseguem, pessoalmente, face a face, estabelecer um diálogo maduro, uma relação autêntica com o outro. A virtualidade, ao mesmo tempo em que pode globalizar as relações, também é capaz de esfriar os sentimentos, mascarar a realidade e alienar a pessoa em seu mundo próprio. Revelase, assim, a face de toda uma sociedade: individualista, onde cada um constrói seu mundo, pensa e age por si mesmo.

Uma relação autêntica entre os humanos e do próprio homem com seu meio foi esfacelada e vem degradando-se ainda mais nas experiências vivenciais das pessoas. Quando se volta unicamente para si, o ser humano faz de tudo o que o rodeia um objeto do qual pensa poder utilizar-se para conseguir o que quer. Esta mentalidade, inaugurada pelos instintos de poder e de dominação, pode ser denominada antropocentrismo, o grande mal deste século. Colocando-se no centro, o homem aproveita-se de forma irresponsável das coisas e faz da natureza sua servidora, pensando que tudo deve girar em torno dele e servi-lo em todas as suas vontades. " $\mathrm{O}$ antropocentrismo considera o ser humano rei/rainha do universo. Considera que os demais seres só têm sentido quando ordenados ao ser humano; eles estão aí disponíveis ao seu bel-prazer" (BOFF, 2000, p. 29).

Ainda mais, a característica ética antropocêntrica coloca o homem como inimigo da natureza, já que faz a pessoa pensar única e exclusivamente em si e em seus interesses e despreocupar-se com o outro e com a natureza, afastando-se do próprio Deus, originador e doador do dom máximo da humanidade, a vida (ARRUDA, 2000a. p. 32).

Tal característica da sociedade atual, o antropocentrismo, é considerada como o principal fator a partir do qual podemos falar em crise de valores. O pensamento individualista e egocêntrico constitui, atualmente, a maior ameaça à extinção da vida: da Terra, dos seres animados, inclusive o ser humano, das relações vivas estabelecidas, da geração presente e até da futura.

Tal antropocentrismo, inaugurado no pensamento moderno e em especial por Descartes $^{3}$, causou e continua a causar grande impacto negativo e destrutivo à Terra, mantenedora e Mãe da vida. O homem moderno, colocando-se no centro de universo e dominando destrutivamente a natureza, pensava que os recursos naturais fossem ilimitados. "No imaginário dos fundadores da sociedade moderna, o desenvolvimento movia-se dentro de dois infinitos: o infinito dos recursos naturais e o infinito do desenvolvimento rumo ao futuro". (BOFF, 2000. p. 28). Porém, tal utopia mostrou-se ilusória, já que constatamos, na escassez e falta dos recursos naturais evidenciados

\footnotetext{
${ }^{3}$ A partir de Descartes cabe ao homem a tarefa de constituir o universo. Assim, o ser humano começa a se pensar como um Deus mortal, capaz de conhecer, trabalhar e aperfeiçoar a natureza circundante. A ordenação do mundo é possibilitada pela subjetividade, ou seja, o mundo é aquilo que é posto pelo sujeito. A natureza é vista como um objeto, destinada unicamente a satisfazer as necessidades humanas. [Cf. FAENELLO, Anderson Francisco. René Descartes: dúvida como método e certeza como busca. Disponível em: <http://pt.shvoong.com/humanities/philosophy/1809280-ren\%C3\%A9descartes-d\%C3\%BAvida-como-m\%C3\%Agtodo/\#ixzzıwOiK8rEI>. Acesso em: o1 mai. 2012].
} 
atualmente, que tais recursos são limitados e finitos. Assim, da mesma forma o desenvolvimento futuro também pode ser limitado. A ciência e a técnica que visavam o progresso a todo custo esqueceram-se que, para serem eficazes e contínuas precisavam também ser sustentáveis. Tornaram-se assim, vorazmente destrutivas, entendendo a Terra como um objeto.

Toda a Terra foi reduzida a ser capital natural, um conjunto de recursos para a acumulação e benefício, primeiro para os setores que detinham a propriedade privada destes recursos e em segundo plano para os outros. E os trabalhadores foram reduzidos a capital humano. O resultado atual é devastador. As relações sociais hoje, a nível mundial, são de grande destrutividade da natureza e de grande exclusão social. Predomina uma relação injusta e humilhante diante da Terra. [...] Grita a Terra e gritam os pobres, ambos vítimas da injustiça social e da injustiça ecológica (BOFF, 1995, p. 7).

Este grito que clama a Terra, angustiada pelas dores causadas durante tanto tempo de civilização humana irresponsável, é fruto de uma construção social que, principalmente na atualidade, não considera como primordial a vida, mas os prazeres individuais, que impedem o desenvolvimento da vida como um todo integrado.

O tipo de sociedade construída nos últimos 400 anos impede realizar um desenvolvimento sustentável. Ela é energívora, montou um modelo de desenvolvimento que pratica sistematicamente a pilhagem dos recursos da Terra e explora a força de trabalho (BOFF, 1995, p. 27-28).

Também na dimensão da produção humana, do trabalho, a destruição gradativa acontece.

Na medida em que foi avançando neste afã objetivista e coisificador, o ser humano criou aparatos que lhe dispensaram o desgaste das energias e aumentaram as potencialidades de seus sentidos. Hoje, mais e mais o trabalho é feito por máquinas, computadores, autômatos e robôs que substituem, em grande parte, a força de trabalho humano. Surge o que se convencionou chamar cibionte: o superorganismo híbrido, feito de seres humanos, máquinas e redes de informação. Destarte se forma a articulação do biológico, do mecânico e do eletrônico que constituem a base de nossas sociedades atuais (BOFF, 1999, p. 94).

Mesmo que a globalização e a tecnologia sejam marcas de nosso tempo e possam ajudar no crescimento econômico, as máquinas e aparatos eletrônicos devem servir de auxílio e suporte à produção, à criatividade e ao esforço humano, e jamais de substituto a eles. Quando se pensa em máquinas para produção trabalhista, já se pensa no lucro gerado com o menor custo, configurando o poder acima de tudo, a fim de dominar e conseguir o que se quer a serviço de interesses próprios. 
No atual mundo unipolar do mercado, a globalização centrada na ética do mercado total é a globalização competitiva, a globalização das desigualdades, a globalização da segurança e do fausto para poucos, da ilusão de um presente eternamente feliz para aqueles que podem "consumir", e da opressão, subordinação ou exclusão para a maioria (ARRUDA, 200oa. p. 43).

\subsection{Crise ambiental - Crise social}

Ao tocarmos no assunto da competitividade na globalização e no mercado, alimentado exaustivamente pelo sistema capitalista e consumidor, logo entramos numa segunda consequência da destruição e de crise dos verdadeiros valores: a destruição da ecologia social (Cf. GUATTARI, 1995. p. 32-33). Este é um importante e fundamental reflexo do antropocentrismo voraz, além da exclusão ecológica e da devastação da Terra: a exclusão e exploração do pobre, daquele que, por efeitos múltiplos, é marginalizado e deixado em condições de vida sub-humanos sem atendimento social e tratamento humanitário necessários para uma vivência, no mínimo, digna. Vemos assim, a relação necessária existente entre pobreza e ecologia dentro da realidade da crise atual.

Os excluídos o são econômica, cultural e politicamente, mas também ecologicamente. As mesmas causas que os marginalizam dos processos econômicos, da dinâmica cultural e da vida política, também os empurram e forçam a ocupar os piores e mais impróprios ambientes. É exatamente no ambiente da pobreza que coincide a pobreza social com a pobreza ecológica (GUDYNAS, 1995, p. 130)

Tudo o que se faz contra a vida reflete-se em todas as suas manifestações, pois a força vital que anima todo ser também os interliga, conecta todos com todos, e faznos responsáveis com todos. Logo, tal exclusão social é reflexo da exclusão e indiferença em relação à natureza e torna-se, deste modo, exclusão ecológica.

A exclusão ecológica sofrida pelos mais pobres possui várias características. Em primeiro lugar, os setores excluídos são levados a ocupar os ambientes de pior qualidade. [...] Encontram-se em áreas sujeitas à inundação, aos deslizamentos de terra ou a tormentas (GUDYNAS, 1995, p. 130).

Ainda outras características podem ser elencadas: difícil acesso à água potável e ao saneamento básico, falta ou má qualidade do atendimento social, habitacional (precisando improvisar a própria habitação), de saúde e de acesso à educação escolar.

A exclusão ecológica (viver onde ninguém quer viver) reforça a exclusão social. [...] A maioria se integra aos circuitos econômicos informais, que são frágeis e instáveis, sem proteção legal e que lhes trazem ganhos insignificantes. [...] Nas cidades, os grupos humanos mais pobres passam a viver na periferia, junto às vias e estradas de acesso ou aproveitando o entroncamento com viadutos, pontes e 
riachos. Outros invadem áreas abandonadas dentro das cidades. [...] Também existe exclusão, com um forte conteúdo ecológico, no acesso ao trabalho. Para muitos pobres, conseguir um trabalho mais ou menos estável é um sonho, e por isso acabam aceitando trabalhar onde ninguém quer. Submetem-se a empregos em condições ambientalmente negativas, às vezes com risco à saúde, aspirando gases tóxicos, expostos a ruídos ensurdecedores ou correndo risco de acidentes. No campo, a extrema pobreza leva a práticas de sobrevivência que causam impacto negativo sobre os recursos naturais. Alguns se veem obrigados a dedicar-se à caça clandestina, [...] outros exploram excessivamente seus solos. [...] a ocupação de terras de má qualidade, a falta de acesso à água, a impossibilidade de recursos adicionais para melhorar seus cultivos ou a criação de gado acabam gerando uma maior degradação ambiental, ao mesmo tempo que aumenta a pobreza (GUDYNAS, 1995, p. 130-131).

A racionalidade extrema, em vista do progresso pela exploração do homem e da natureza, não levou a resultados positivos. Projetos embasados no puro sentimentalismo não levam a um comprometimento sério perante as decisões a serem tomadas. Assim, o segredo encontra-se na sustentabilidade: utilizar-se dos meios da Terra em benefício comum de forma cuidadosa e responsável, ou seja, equilibrando a razão técnica e o sentimento de compaixão. Sabendo equilibrar a racionalidade e o sentimento veremos que a natureza, já tão castigada, não é apenas objeto de consumo do qual me utilizo para meu bem pessoal irrefreado, mas sim é um ecossistema no qual estou inserido, podendo utilizar-me dele para o bem próprio e coletivo de forma responsável e sustentável. Traduzimos isto numa expressão denominada 'modo-de-ser-trabalho interativo'.

O modo-de-ser-no-mundo pelo trabalho se dá na forma de interação e de intervenção. O ser humano não vive numa sesta biológica com a natureza. Pelo contrário, interage com ela, procura conhecer suas leis e ritmos e nela intervém para tornar sua vida mais cômoda. É pelo trabalho que faz tudo isso. Pelo trabalho constrói o seu "habitat", adapta o meio ao seu desejo e conforma seu desejo ao meio. Pelo trabalho prolonga a evolução e introduz realidades que, possivelmente, a evolução jamais iria produzir, como um edifício, uma cidade, um automóvel, uma rede de comunicação por rádio e televisão. Pelo trabalho copilota o processo evolutivo, fazendo com que a natureza e a sociedade, com suas organizações, sistemas e aparatos tecnológicos, entrem em simbiose e coevoluam juntas (BOFF, 1999, p. 93).

De certa forma, ecologia e pobreza estão intimamente ligadas, e são faces diversas de uma mesma realidade: agressão e violação da vida por interesses individuais e antropocêntricos. "Tanto a pobreza social como a destruição ambiental são na realidade sintomas de um problema mais profundo: um tipo de desenvolvimento espoliativo, obsediado com eficiência e maximização, e que manipula e domina, tanto o ser humano como a Natureza" (BOFF. 1999. p. 133). 
Precisamos de valores que permitam o desenvolvimento sustentável, que nos deem a possibilidade da utilização dos meios naturais sem consequências ulteriores à Terra e aos seres viventes. Precisamos de um novo paradigma de desenvolvimento integral, que reintegre a Terra e suas ecologias. "A solução dos problemas ambientais é atualmente impensável se não forem solucionados os problemas da pobreza e da exclusão" (BOFF. 1999. p. 135).

\subsection{Os sintomas da crise e as pistas de ação}

Diante da realidade socioambiental do modelo de nossa civilização, percebemos grandes contradições, valores perdidos, quebrados e fragmentados. É uma visão

[...] marcadamente individualista, atomista, fragmentária e mecanicista. A consequência prática desta visão é que cada indivíduo, empresa, grupo social e nação se vê como absoluto e vê o outro como um competidor, uma ameaça, um inimigo contra o qual guerrear, numa lógica de derrotar ou ser derrotado (ARRUDA, 200ob. p. 145).

"O sintoma mais doloroso [...] é um difuso mal-estar da civilização. Aparece sob o fenômeno do descuido, do descaso e do abandono, numa palavra, na falta de cuidado" (BOFF, 1999, p. 18). Sendo a vida o dom mais precioso e da qual depende todo tipo de existência animada e dinâmica, ferindo uma de suas dimensões, acaba-se por atentar contra todo o resto. A rede da vida é como um corpo humano: machucando um pé, os outros membros sentirão também a dor e a dificuldade correspondente. A cada sinal de descuido e de morte precisamos pensar nas consequências e nos tantos outros que sofrem.

Há um descuido e descaso pela vida inocente de crianças usadas como combustível na produção para o mercado mundial. [...] Há um descuido e descaso manifestos pelo destino dos pobres e marginalizados da humanidade, flagelados pela fome crônica, mal sobrevivendo da tribulação de mil doenças.[...] Há um descuido e descaso imensos pela sorte dos desempregados e aposentados, sobretudo dos milhões e milhões de excluídos do processo de produção, tidos como descartáveis e zeros econômicos. [...] Perderam o privilégio de serem explorados a preço de um salário mínimo e de alguma seguridade social (BOFF, 1999, p. 18).

O impacto ambiental é agravado pelo impacto social. A cada menor explorado, a cada pobre marginalizado, a cada aposentado descartado, a cada pessoa tida como objeto de consumo e produção, revela-se um sistema brutal onde sequer a vida humana é respeitada com a devida dignidade. Se a vida do ser humano, que pode reagir instantaneamente e defender-se, é explorada e descartada facilmente, como não é explorada a vida ecológica, a Terra em seus variados recursos: depois de 
explorada impensavelmente, é descartada sem nenhuma compaixão. O impacto e degradação ambiental que presenciamos nas fúrias naturais são reflexos da degradação da vida humana social, que requer também uma resposta à altura.

Há um descuido e abandono dos sonhos de generosidade, agravados pela hegemonia do neoliberalismo com o individualismo. [...] Há um descuido e abandono crescentes da sociabilidade nas cidades. A maioria dos habitantes sente-se desenraizada culturalmente e alienada socialmente. Predomina a sociedade do espetáculo, do simulacro e do entretenimento (BOFF, 1999, p. 18-19).

Ainda em âmbito social, o crescente individualismo faz-nos perceber a demasiada exaltação e predileção pelas coisas particulares e o esquecimento indiferente do alheio, do outro, da coletividade. Não cansamos de ver, nas grandes cidades, aglomerados de pessoas que nem se olham, casas com muros altos, cercas elétricas e guardas. Sinal de desconfiança do outro, já que não se tem nem o mínimo de segurança pública. Num sistema social injusto e exploratório, é melhor prevenir-se no comodismo do 'meu mundo' que arriscar conhecer e compartilhar o 'mundo do outro'. Cada um cria seu mundo e refugia-se nele, esquecendo-se da cooperação, da fraternidade. Esquece-se que o mundo é de todos e que a Terra nos reúne, congrega e acolhe.

Há um descuido e descaso generalizados na forma de se organizar a habitação, pensada para famílias minúsculas, obrigadas a viver em cômodos insalubres. Milhões e milhões são condenados a viver em favelas sem qualquer qualidade de vida, sob a permanente ameaça de deslizamentos, fazendo a cada ano milhares de vítimas. As formas de vestir de estratos importantes da juventude revelam decadência dos gostos e dos costumes. Recorre-se frequentemente à violência para resolver os conflitos interpessoais e institucionais, normalmente superáveis mediante o diálogo e a mútua compreensão (BOFF, 1999, p. 20).

Destarte, as desigualdades da exploração social, os próprios costumes, gostos e maneiras de portar-se perante os outros, revelam-nos acentuada decadência cultural e moral. É a fragmentação da ecologia mental, dominada pelo serialismo da mídia, onde as massas são alienadas em séries, a se comportar, vestir, ouvir e comer conforme ditam as mídias e modas (Cf. GUATTARI, 1995. p. 11). Não afirmamos que o que é antigo ou passado foi melhor, deixando-nos guiar por um saudosismo doentio. O novo, a novidade, a inovação é positiva e, usada correta e conscientemente, ajuda no crescimento e desenvolvimento-abertura à realidade presente. Porém, o que se deve combater é justamente o cultivo de uma subjetividade descompromissada, fora da realidade, alienante e massificadora. Toda forma de identidade pessoal ou de identificação com determinado estilo de vida ou de costumes deve, em primeira instância, garantir a verdadeira liberdade e preservação dos fundamentais valores, sejam eles sociais, ambientais e pessoais. 
Tal ecologia mental deve, portanto, levar a

[...] reinventar a relação do sujeito com o corpo, com o fantasma, com o tempo que passa, com os "mistérios" da vida e da morte. Ela será levada a procurar antídotos para a uniformização midiática e telemática, o conformismo das modas, as manipulações da opinião pela publicidade, pelas sondagens etc. ${ }^{4}$.

Como já lembrado, são descompromissos existenciais, sociais, morais e subjetivos que nada mais são que reflexos daquele descompromisso fundamental com a vida e a Terra.

Há um descuido e descaso pela dimensão espiritual do ser humano. [...] Não há cuidado pela inteligência emocional. [...] Todo tipo de violência e de excesso é mostrado pelos meios de comunicação com ausência de qualquer pudor ou escrúpulo (BOFF, 1999, p. 19).

Quando se abandona o cuidado ambiental, social e pessoal para com a vida, perde-se também o cuidado pela dimensão espiritual do ser humano, abandona-se a busca pelo que permanece, pelo que é perene, eterno e do qual não se pode fugir. 5 Assim, nada pode preencher o homem, já que, negando sua inclinação natural ao que é infinito, apega-se ao que mais enche os olhos e chama a atenção no momento, porém logo passa. Deixando-se de lado o infinito, permanece a eterna procura pela saciedade, a qual nunca é preenchida. A cada vez que procura, o homem fica mais obcecado e é capaz até de destruir para conseguir o que deseja. É assim que acontece com a Terra, Mãe providente do sustento. Quando se consome além do limite, sem pensar na preservação, seja da água, dos frutos, dos alimentos, das necessidades materiais da natureza, se destrói a esplêndida dinâmica e beleza da vida.

"Há um descuido e um descaso pela coisa púbica, [...] pelo nível moral da vida pública marcada pela corrupção e pelo jogo explícito de poder" (BOFF, 1999, p. 19). Quando a pessoa se acostuma a fazer o que não é correto, isto se torna um hábito. Tanto se faz que já ninguém mais percebe ou dá importância. A cada vez que se

\footnotetext{
${ }^{4}$ GUATTARI, 1995, p. 16. Quando Guattari se refere nesta citação à reinvenção da relação do sujeito "com o fantasma", ele se refere ao fantasma inconsciente, no sentido psicanalítico, ou seja, à própria interioridade, à relação com sua subjetividade, senda esta um fantasma, um mistério, uma caverna assombrada a ser descoberta a cada momento.

${ }^{5}$ Fala-se que não se pode fugir, pois a eternidade, o próprio desejo de permanecer, de algo maior, é próprio do humano. Pela dimensão espiritual o homem espera sempre mais, espera algo mais perfeito. Na visão cristã, pela morte isto se realiza. O cristão "entende a vida como lugar de realização da utopia do Reino de Deus, que é de vida e de liberdade seminal aqui e plena na eternidade. A morte é passagem para a plenitude do Reino. Ela é des-dramatizada, pois no momento da morte dá-se logo a ressurreição. Por isso, dizia o poeta e místico D. Pedro Casaldaliga: a alternativa cristã é esta: ou vida ou ressurreição". Nesta dimensão espiritual, na qual se abre o horizonte da morte que na realidade é permeada de plenitude e perfeição, cada homem precisa enfrentar e responder por si: "a morte é relegada a um problema da subjetividade individual. Cada qual tem de se haver com ela. Ninguém pode ser substituído no seu morrer. Cada um deve-lhe conferir uma significação ou negar qualquer esperança para além deste mundo". Cf. Id., 2000. p. 220-221.
} 
rouba, que se defrauda, que se desvia dinheiro destinado a um objetivo de construção e de melhora para a qualidade de vida, alimentam-se os sinais de morte, de retrocesso, e deixa-se a vida digna e humana de lado.

Há um abandono da reverência, indispensável para cuidar da vida e de sua fragilidade. [...] Há um descuido descaso na salvaguarda de nossa casa comum, o planeta Terra. Solos são envenenados, ares são contaminados, águas são poluídas, florestas são dizimadas, espécies de seres vivos são exterminadas (BOFF, 1999, p. 19-20).

Com a junção destes fatores, a cultura do isolamento e do individualismo gerando a quebra dos valores coletivos e intersubjetivos, o desejo de crescimento e desenvolvimento material e produtivo como forma de poder e dominação para autoafirmação, cria-se uma ruptura crucial na existência humana: a quebra da relação com a transcendência.

Com efeito, o ser humano da modernidade entrou num acelerado processo de secularização. Não precisa de Deus para legitimar e justificar os pactos sociais. [...] O ser humano moderno criou um "complexo de Deus". Comportou-se como se fora Deus. Através do projeto da tecnociência, pensou que tudo podia, que não haveria limites à sua pretensão de tudo conhecer, de tudo dominar e de tudo projetar. Essa pretensão levou-o a exigências exorbitantes a si mesmo. Ele não aguenta mais tanto desenvolvimento que já mostra componente destrutivo, ao ameaçar o destino comum da Terra e de seus habitantes. Irrompeu nele "o complexo de Deus" que o acabrunha (BOFF, 1999, p. 21).

Percebendo a necessidade de uma unidade integral para si e para as coisas, o ser humano deve reconhecer que tal unidade não pode ser resultado de ação externa, passageira e transitória; a unidade provém do que é interno, de natureza além da aparente, e deve ser perene, logo, espiritual. Na concepção cristã dá-se o papel de unificador da vida e de sua diversidade a Deus. Esquecendo-se de Deus, o homem perde seu elo de unidade (BOFF, 2000, p. 212).

A tecnicidade e o instinto dominador do ser humano acabam por engolir Deus, deixando-o de lado e rompendo o elo de relação com Ele. Negando uma espiritualidade autêntica e necessária para sua unidade integral, o homem acaba tendo que preencher tal vazio dentro de si. Pelo sistema individualista e antropocêntrico construído por ele mesmo, e achando-se detentor de todo poder sobre a relação do dinamismo vital, o homem acaba colocando-se no lugar de Deus, e diante de tamanha pretensão termina por não medir suas próprias consequências. Negando sua integral constituição (social e subjetiva, ambiental imanente e transcendente), o ser humano acaba por fragmentar-se.

Para reverter este quadro lastimoso e recolocar Deus em seu lugar originário, o próprio homem precisa reconhecer-se como de fato é. 
A condição indispensável para uma verdadeira metanoia é a disposição de abdicar do orgulho, de reconhecer honestamente e admitir que estamos equivocados. No caso do grave perigo em que estamos colocando a Terra e toda a vida, inclusive a nossa, é preciso reconhecer humildemente que somos apenas criaturas nesta Terra (VELASQUEZ, 1995, p. 73).

Cada ser humano precisa tomar consciência de sua realidade, como uma pequena parcela da criação, uma mera criatura na grandiosidade da vida e da Terra, para assim integrar-se com toda a complexidade vital por uma espiritualidade autêntica. "Formalizando, a espiritualidade é aquela atitude pela qual o ser humano se sente ligado ao todo, percebendo o fio condutor que liga e religa todas as coisas para formarem o cosmo" (BOFF, 2010, p. 104). Ao invés de pensarmos e agirmos como Deus, precisamos suscitar o sopro de Deus que há em nós: sopro do cuidado, do respeito e da reverência diante da manifestação da vida.

Precisamos superar a espiritualidade do eu. Não somos Deus e não o poderemos ser. Esta experiência já foi atestada nos tempos passados. Quando tenta colocar-se em posição superior à que lhe pertence, o homem não consegue controlar seus impulsos. À medida que ganha mais, mais quer. E isto faz pela exploração, manipulação e, por consequência, pela destruição.

\section{As novas perspectivas sobre os problemas de sempre}

Como resultado de uma construção histórica trilhada pelos homens e mulheres do passado, e ainda no presente, estamos diante de uma realidade atual insustentável. Com o pensamento moderno, inaugurando o afã centralizado no homem, em suas vontades, utilizando-se da natureza para mais produzir e lucrar, a Terra foi altamente prejudicada. E hoje nós, seres humanos do nosso tempo, estamos sentindo as consequências de tudo isso (Cf. BOFF, 2010, p. 16).

A ética atual não pode mais continuar a sustentar-se com base nos valores falsos que até agora eram absolutizados: centralidade e referência no homem e na razão, exploração para o consumo, infinitude dos recursos naturais, matematização da natureza para aproveitamento máximo. Segundo Hans Jonas ${ }^{6}$, a ética antiga

[...] fundava-se e acontecia apenas dentro dos limites do ser humano,

\footnotetext{
${ }^{6}$ Hans Jonas nasceu em 1903, em Möchengladbach, Alemanha. Estudou filosofia e teologia em Freiburg, Berlim e Heidelberg. Foi aluno de Martin Heidegger e de Rudolf Bultmann. No período em que Hitler ascendeu ao poder, Jonas fugiu para a Inglaterra, foi membro do exército britânico, e depois foi para a Palestina. Mudou-se finalmente para New York (EUA), onde viveu até sua morte em 1993. Influenciado pela analítica existencial de Heidegger, pela fenomenologia de Husserl, pela leitura cristã, crítica das perspectivas éticas clássicas e modernas, de Bultmann e pelos horrores dos campos de concentração nazista, concentrou-se em construir uma teoria ética que fizesse frente à presente possibilidade de a humanidade destruir-se utilizando o enorme avanço tecnológico contemporâneo. [GOYA, Will. Resenhas de um clássico. Disponível em: <http://www.filosofia.com.br/vi_classic.php?id=18>. Acesso em: 10 mar. 2012.].
} 
não afetando a natureza das coisas extra-humanas. A natureza não era objeto da responsabilidade humana, pois cuidava de si mesma. A ética tinha a ver apenas com o aqui e o agora (JONAS, 2006, p. 16).

A experiência agora nos mostra que este modelo de sociedade e de construção de pensamento não corresponde mais à necessidade atual. Precisamos transformar todo quadro de destruição já vivido em ações e vivências autenticamente sadias e vivas, e que garanta dinâmica e vitalidade à realidade presente, à sociedade e à convivialidade dos homens entre si e com a natureza.

Fala-se, logo, de uma transformação de modo de vida, de maneiras de viver, pensar e se relacionar. Assim, cria-se um pano de fundo novo, que exige uma fundamental ajuda da filosofia. Por ela podemos enveredar pelo caminho do pensamento crítico, da reflexão fundamentada não mais nos falsos valores, mas nos valores que garantam uma base sólida para uma harmônica convivialidade (Cf. BOFF, 2010. p. 98). Pelo instrumento do raciocínio e reflexão filosófica podemos elencar pontos e pistas de ações práticas que permitam uma verdadeira e integral experiência homem-Terra. Com a filosofia não se quer pensar e refletir as partes separadamente, nem apenas com a unilateralidade racional, mas procura-se um olhar aberto a integralidade da realidade, em todas as dimensões e por todos os meios. Assim, os resultados podem ser efetivos, certos e abrangentes, modificando toda a realidade, em todas as dimensões com a maneira mais adequada para cada situação.

\subsection{Humano-terra: uma unidade holística}

Uma atitude básica que pode ajudar neste processo de reencantar-se pela Terra é a identificação mútua, quando o ser humano se percebe um com a Terra e responsável por ela. Precisamos avivar em nós uma consciência diferente da que se percebe imperante na sociedade atual. Precisamos suscitar uma consciência de unidade, pertença e comunhão. Faz-se mister compreender "[...] que somos parte e parcela do planeta Terra. [...] O ser humano é a própria Terra enquanto pensa, sonha, simboliza, ama e adora. Essa consciência planetária nos faz cidadãos terrenais e corresponsáveis pelo destino de nossa nave espacial azul-branca, esplendorosa, nossa pátria/mátria comum" (BOFF, 2010. p. 174).

Pertencemos à Terra; somos filhos e filhas da Terra; somos Terra. Daí que homem vem de húmus. Viemos da Terra e a ela voltaremos. A Terra não está à nossa frente como algo distinto de nós mesmos. Temos a Terra dentro de nós. Somos a própria Terra que, na sua evolução, chegou ao estágio de sentimento, de compreensão, de vontade, de responsabilidade e de veneração. Numa palavra: somos a Terra no seu momento de auto realização e de autoconsciência (BOFF, 1999, p. 72).

Antes do sentimento, precisamos reconhecer o real lugar da Terra como a grande acolhedora da vida. Precisamos combater o paradigma moderno do 
antropocentrismo, no qual a razão e a vontade individual ditavam as regras de exploração da natureza, danificando-a, depredando-a e esgotando-a.

A globalização e a tecnologia atual devem contribuir para ajudar as pessoas, países e grupos sociais, mas sem ignorar o que de fato é essencial. Elas devem ser, sem dúvida, ecocêntricas. Precisam não beneficiar alguns, mas a Terra como o grande superorganismo, ao qual todos devem se subordinar. Satisfazer as necessidades individuais e também coletivas, dos grupos, comunidades e nações, com a consciência de que não estamos isolados, mas fazemos parte da mesma Casa, e que por ela e por todos os outros habitantes temos responsabilidade (BOFF, 1999, p. 22).

Assim, o próprio 'sentir-se Terra' nos abre, agora, a uma nova dimensão, e à possibilidade de nos reencantarmos por ela; faz-nos atentos a ela como a nós mesmos; sabendo o que é necessário e bom para nós, saberemos também o que o é em relação à Terra.

Sentir que somos Terra nos faz ter os pés no chão. Faz-nos desenvolver uma nova possibilidade para com a Terra, seu frio e calor, sua força, às vezes ameaçadora, às vezes encantadora. Sentir a Terra é sentir a chuva na pele, a brisa refrescante no rosto, o tufão avassalador em todo o corpo. Sentir a Terra é sentir a respiração nas entranhas, os odores que nos embriagam ou nos enfastiam (BOFF, 1999, p. 76).

E saber que tudo isso nos é dado de graça nos dá um grande peso de responsabilidade. Ter a beleza da vida da Terra por gratuidade do Criador e saber que ela depende de nosso zelo, de nossa atenção e sensibilidade, nos faz sentirmos importantes, como protagonistas de uma nova era ecológica. Assim nosso viver, ás vezes rotineiro, se embeleza e enternurece com estas pequenas singelezas da força vital da Terra.

Sentir a Terra é sentir seus nichos ecológicos, captar o espírito de cada lugar, inserir-se num determinado local, onde se habita. Aí habitando, nos fazemos de certa maneira prisioneiros de um lugar, de uma geografia, de um tipo de clima, do regime de chuvas e ventos, de uma maneira de morar e de trabalhar e de fazer história. Ser Terra é ser concreto, concretíssimo. Configura o nosso limite. Mas também significa nossa base firme, nosso ponto de contemplação do todo, nossa plataforma para poder alçar voo para além desta paisagem e deste pedaço de Terra (BOFF, 1999, p. 76-77).

Por isso é tão importante termos a visão do todo e a consciência holística. Falando holisticamente, "[...] as diferenças revelam a complexidade e a riqueza única da humanidade" (BOFF, 2010, p. 98). E toda esta diferença e riqueza “[...] convergem para aquilo que é do interesse coletivo, como a salvaguarda do patrimônio natural e cultural comum e a manutenção da reprodução e desenvolvimento da vida humana e de todas as outras formas de vida e de ser" (BOFF, 2010, p. 98). Estamos inseridos 
num determinado contexto e em determinada geografia; mas, se não cuidarmos nem de nosso pedaço, afetaremos o todo, já que a força da vida funciona como uma rede, interligada e interconectada. Justamente

[...] a perspectiva holística não significa o somatório dos pontos de vista (que são sempre a vista de um ponto), mas a capacidade de ver a transversalidade. Quer dizer, a capacidade de detectar os interretrorrelacionamentos de tudo com tudo. Economia, gestão e cálculo têm a ver com filosofia, física, arte e religião. Nada existe justaposto ou desvinculado do todo (BOFF, 2010, p. 98).

Este ver holístico não quer dizer o fundar uma nova ética, novos paradigmas e conjuntos de modos de vida, mas perceber nas entrelinhas de tudo o que já existe aquela boa intenção, a boa vontade, que Kant cita como princípio de qualquer discurso ético, da organização e cuidado pelo que há de mais valioso e universal, o cuidado pela casa comum, a Terra, sempre almejando o bem conviver de todos com tudo (BOFF, 2010, p. 99). Não podemos ignorar o agora, pois a partir dele construiremos o depois; não podemos ignorar o aqui, pois a partir dele construiremos o acolá. "Por fim, sentir-se Terra é perceber-se dentro de uma complexa comunidade com seus outros filhos e filhas. [...] Sentir-se Terra é mergulhar na comunidade terrenal, no mundo dos irmãos e irmãs, todos os filhos e filhas da grande e generosa Mãe, a Terra” (BOFF, 1999, p. 77).

\subsection{A essencialidade do cuidado na relação humano-terra}

Uma diferença que precisamos fazer para não entendermos mal o papel do ser humano neste novo paradigma: “[...] um modo-de-ser não é um novo ser. É uma maneira do próprio ser de estruturar-se e dar-se a conhecer. $O$ cuidado entra na natureza e na constituição do ser humano. O modo de ter cuidado revela de maneira concreta como é o ser humano" (BOFF, 2010, p. 34). O homem não precisa nascer de novo para assumir-se "um ser de cuidado".

O novo paradigma não se torna uma semente plantada pela geração atual a fim de ser colhida e começar a se desfrutar num futuro próximo ou distante. É este homem atual que precisa assumir-se como homem de constituição nova, semeando e colhendo frutos bons agora, vivendo e experimentando esta nova aventura de ser: a era planetária, do cuidado com a Terra e com a vida (BOFF, 2010, p. 23).

Assim revela-se a verdadeira e essencial face da mudança que precisa acontecer: ela é ontológica, essencial. O homem não deixa de ser homem, porém assume a verdadeira realidade que o faz ser de fato humano. Não se engana mais, mas assume sua verdadeira essencialidade: o ser homem-cuidado.

Sem o cuidado, ele deixa de ser humano. Se não receber cuidado, desde o nascimento até a morte, o ser humano desestrutura-se, definha, perde sentido e morre. Se, ao largo da vida, não fizer com 
cuidado tudo o que empreender, acabará por prejudicar a si mesmo e por destruir o que estiver à sua volta. Por isso, o cuidado deve ser entendido na linha da essência humana (HEIDEGGER apud BOFF, 1999, p. 243).

Este, justamente, é o diferencial que faz do homem alguém capaz de transformar a realidade atual dando esperança às futuras gerações. "Não temos cuidado. Somos cuidado" (BOFF, 2010, p. 89). O cuidado é o remédio para uma realidade ferida. Na atualidade, diante da globalização e tecnologia, uma máquina, mesmo realizando o dobro do trabalho de uma pessoa em menos tempo, não o faz em sua inteireza, já que lhe falta o cuidado-amor essencial.

Há algo no ser humano que não encontramos nas máquinas, surgido há milhões de anos no processo evolutivo quando emergiam os mamíferos, dentro de cuja espécie nos inscrevemos: o sentimento, a capacidade de emocionar-se, de envolver-se, de afetar-se e de sentirse afetado. Um computador e um robô não têm condições de cuidar do meio ambiente, de chorar sobre as desgraças dos outros e de rejubilar-se com a alegria do amigo. Um computador não tem coração (BOFF, 2010, p. 99).

Quando se respeita a vida em primeiro lugar, não se pensa apenas em si, mas em todos. Quando a vida é respeitada, trabalha-se para o bem comum, para o saneamento a todos, moradia digna, alimentação saudável, educação de qualidade, acesso à saúde, à liberdade religiosa, organização social transparente, enfim, para uma ecologia ambiental, social e mental-afetiva saudáveis.

Precisamos reconhecer e respeitar "[...] a trama vital que anima os ecossistemas" (GUDYNAS, 1995, p. 135-136). Quando se coloca a vida no centro, o desenvolvimento torna-se integral. Quando o cuidado pela vida nos invade, o apelo do outro, do pobre e do excluído socialmente nos move, nos faz sentir junto com ele e nos anima à solidariedade, à ajuda mútua, à real cooperação. Por isso que o sentimento deve tomar partida na nossa mudança de paradigma, pois ele nos impele a mudar. "Importa colocar cuidado em tudo" (BOFF, 1999. p. 102). Precisamos reavivar em nós "[...] a capacidade de sentir o outro, de ter compaixão com todos os seres que sofrem, sendo eles humanos e não humanos, de obedecer mais à lógica do coração, da cordialidade e da gentileza do que à lógica da conquista e do uso utilitário das coisas" (BOFF, 1999. p. 102).

A própria palavra 'cuidado' em sua etimologia já nos ensina. Ela provém do latim cura e era costumeiramente usada nesse idioma no contexto do restabelecimento das relações do amor ou amizade profunda (BOFF, 1999. p. 90). Este cuidado representa um interesse ativo (aquele que nos impele e nos faz mudar as situações), uma preocupação com algum sinal de morte ou doença, para tornar-se remédio eficaz que cura feridas. "Este é o modo de ser que resgata a nossa humanidade mais essencial” (BOFF, 1999. p. 103). 
O cuidado e o amor: duas forças agregadoras de responsabilidade autêntica e integral. "O amor é um fenômeno cósmico e biológico. Ao chegar ao nível humano, ele se revela como a grande força de agregação, de simpatia, de solidariedade. As pessoas se unem e recriam pela linguagem amorosa o sentimento de benquerença $e$ de pertença a um mesmo destino e a uma mesma caminhada histórica" (BOFF, 1999. p. 111). $\mathrm{O}$ amor é intrínseco ao outro. $\mathrm{O}$ amor é sempre um sentimento que gera união. Por isso, nossa relação com a Terra deve ser uma relação de amor, pois a ela pertencemos e nela vivemos. Quando vivemos com amor e existimos orientados pelo amor, damos sentido à própria existência, nossa e do outro.

Amar o outro é dar-lhe razão de existir. [...] Amar o outro é querer que ele exista, porque o amor faz o outro importante. [...] Quando alguém ou alguma coisa se fazem importantes para o outro, nasce um valor que mobiliza todas as energias vitais. É por isso que, quando alguém ama, rejuvenesce e tem a sensação de começar a vida de novo. O amor é a fonte dos valores (BOFF, 2003. p. 47).

O amor é sempre fonte de comunhão, pois me liga e continuamente religa com o outro. Num ambiente de divisão falta essencialmente o amor.

Sem o cuidado essencial, o encaixe do amor não ocorre, não se conserva, não se expande nem permite a consorciação entre os seres. Sem o cuidado, não há atmosfera que propicie o florescimento daquilo que verdadeiramente humaniza: o sentimento profundo, a vontade de partilha e a busca do amor (BOFF, 2003. p. 111-112).

Pelo cuidado e amor queremos instaurar um novo paradigma, um novo modelo de vida e relação entre os que compartilham a força e dinâmica da vida: um modelo de vida sustentável.

A sustentabilidade significa o uso racional dos recursos escassos da Terra, sem prejudicar o capital natural, mantido em condições de sua reprodução, em vista ainda ao atendimento das necessidades das gerações futuras que também têm direito a um planeta habitável. Trata-se de uma diligência que envolve um tipo de economia respeitadora dos limites de cada ecossistema e da própria Terra, de uma sociedade que busca a equidade e a justiça social mundial e de um meio ambiente suficientemente preservado para atender às demandas humanas (BOFF, 2011a, p. 32).

Deste modo precisamos fazer com que todas as relações que estabelecemos sejam sustentáveis: relações político-econômicas (onde o sistema de economia sustente de modo justo e digno a todos), ecológicas (onde possamos aproveitar os recursos que a Terra nos oferece sem eliminá-los), pessoais (de maneira que estabeleçamos relações de carinho, afeto e amizade com as pessoas por gratuidade e consciência de convivialidade), sociais (de forma que todos se ajudem na cooperação e solidariedade entre si e de consciência de preservação ás futuras gerações), de 
consumo (de maneira que o que consumimos ou compramos seja o necessário para uma vida saudável físico e psicologicamente, e o que descartamos seja destinado aos devidos fins e, se possível, reaproveitado) e valorativas (afim de que os valores necessários para preservação no amor, cuidado, responsabilidade e compaixão sejam mantidos e guardados).

Este é o novo modo para reinventar nossa existência autêntica e segura na Terra e em relação com ela. "Sustentabilidade e cuidado devem ser assumidos conjuntamente para impedir que a crise se transforme em tragédia, e para conferir eficácia às práticas que visam fundar um novo paradigma de convivência ser humanovida-Terra" (BOFF, 2011a, p. 32).

\subsection{O cuidado com o corpo}

Toda reflexão que fazemos em nível ecológico, social e político, requer relação. Já vimos como estabelecer relações sustentáveis, saudáveis, que permitam a convivialidade e a perpetuidade do que é essencial. E todo tipo de relação que estabelecemos, direta ou indiretamente, o fazemos mediados pelo nosso corpo. $\mathrm{O}$ corpo é uma categoria necessária para a existência, pois a partir dele estamos no mundo, fazemos parte dele e também por ele enraizamos a experiência para além de nós mesmos (BOFF, 2000, p. 227).

O corpo é aquela porção do universo que nós animamos, informamos, conscientizamos e personalizamos. [...] Corpo é um ecossistema vivo que se articula com outros ecossistemas mais abrangentes. [...] através do corpo se mostra a fragilidade humana. A vida corporal é mortal. Ela vai perdendo seu capital energético, seus equilíbrios, adoece e finalmente morre. A morte não vem no fim da vida. Ela começa já no seu primeiro momento. Vamos morrendo, lentamente, até acabar de morrer. A aceitação da mortalidade da vida nos faz entender de forma diferente a saúde e a doença (BOFF, 2011a, p. 143).

O corpo torna-se uma dimensão do cuidado essencial que por vezes perdemos ou esquecemos. Quando cuidamos do corpo, estamos cuidando das relações e fazendo com que sejam mais profundas e eficazes.

Quando falamos do cuidado com o corpo, em primeira instância falamos de saúde e doença. Quando adoecemos, significa que necessitamos de cuidado especial. Para não adoecermos, requer-se ainda o cuidado preventivo (BOFF, 2011a, p. 143). Nossa saúde, nosso corpo, para que cumpra sua missão e estabeleça as relações necessárias, necessita de cuidado. Cuidado com alimentação saudável, prática de exercícios físicos, visita periódica ao médico, ocupação da mente com trabalhos e atividades sadias, leitura de bons livros e literaturas, cultivar um estilo de vida com alegria e dinamicidade são alguns dos exemplos e das ações que devemos realizar para que, saudáveis, passamos interagir e integrar nosso corpo e nossas relações com a 
realidade complexa da Terra.

O corpo assume uma segunda função: além de organismo físico funcional, é mediador de relações e meio de interação. Desse modo, a saúde torna-se uma maneira de encarar e coexistir com as realidades humanas e não-humanas. "Saúde é acolher a vida assim como se apresenta, alegre e trabalhosa, saudável e doentia, limitada e aberta, ao ilimitado que virá além da morte" (BOFF, 2011a, p. 145). Entendemos deste modo, que saúde é um processo de cuidado do todo, do corpo físico e sua alimentação, do espírito e da interioridade, das relações humanas e afetivas, do nosso ambiente e da nossa casa. Cuidar da saúde e "[...] do corpo significa a busca de assimilação criativa de tudo o que nos possa ocorrer na vida, compromissos e trabalhos, encontros significativos e crises existenciais, sucessos e fracassos, saúde e sofrimento" (BOFF, 2011a, p. 145). Logo, por saúde não se entende estado momentâneo de vida, ausência ou não de dor ou doenças, mas torna-se uma maneira de existir, de encarar as circunstâncias, de viver e se relacionar.

\subsection{A espiritualidade da Terra}

Para uma autêntica existência, que seja sustentável e promova os valores da vida e da dignidade da Terra e do homem, é necessária uma atenção particular à dimensão espiritual do ser humano.

Espiritualidade é aquela atitude que coloca a vida no centro, que defende e promove a vida contra todos os mecanismos de diminuição, de estancamento e de morte. O oposto ao espírito, nesse sentido, não é o corpo, mas a morte e tudo o que estiver ligado ao sistema de morte, tomada em seu sentido amplo, de sistema de morte biológica, morte social e morte existencial (fracasso, humilhação, opressão) (BOFF, 2000, p. 130-131).

Assim, ao despertar-nos para nossa dimensão espiritual, estaremos despertando para o valor essencial da existência do ser humano: o cuidado que gera e promove vida. O ser humano, enquanto ser espiritual não se apega ao que não o alimenta e preenche interiormente. Logo, ao promover o outro e o próprio ambiente onde vive, pelos princípios de amor, cuidado, compaixão e carinho, ele próprio se preenche de todas essas virtudes e se conecta com a Terra e com Aquele que a criou e a deu a nós.

Pela espiritualidade nos reconhecemos, primeiramente,

[...] como um nó de relações, [...] como um projeto infinito. [...] Como ser de relações, ele [o ser humano] somente realiza-se quando for sujeito de sua prática, quando acolher a alteridade do outro, que também é sujeito, e juntos fizerem-se atores de uma história coletiva (BOFF, 2000, p. 2018).

A espiritualidade não pode nascer do poder, da dominação e da ganância, mas da comunhão, do amor, do cuidado, do coração. 
Alimentar a espiritualidade significa estar aberto a tudo o que é portador de vida, cultivar o espaço interior de experiência a partir de onde todas as coisas se ligam e religam, superar os compartimentos estanques, captar a totalidade e vivenciar as realidades para além de sua facticidade opaca, por vezes, brutal, como valores, evocações e símbolos de uma dimensão mais profunda (BOFF, 2000, p. 131).

A espiritualidade, o cultivo do espaço interior pessoal, nos faz sentir com o outro, sentir com a Terra (já que somos a Terra) e, sentindo, compartilhar de suas alegrias e angústias. Um ser humano espiritual é capaz de enxergar o mais profundo da realidade e identificar ali os anseios mais escondidos. Desta forma podemos dar uma resposta á altura. $\mathrm{O}$ cultivo de uma autêntica espiritualidade nos faz sentir-nos incomodados com as situações de morte que atrapalham o desenvolvimento e integração necessários e nos impedem a mudança, a transformação dos sinais de morte em vida e dos sinais de vida em mais vida.

A espiritualidade ainda nos oferece uma dimensão além do visível: símbolos, gestos, invocações que nos conectam com o que está além desta realidade, com uma realidade além, mais alta e última (BOFF, 2000, p. 131). Assim como existe a ecologia exterior, referente ao ambiente em que vivemos e as diversas manifestações da força vital, a espiritualidade nos faz despertar para o cultivo de uma ecologia interior, do universo que está dentro de nós (BOFF, 2000, p. 134). E a partir dele nos faz renascer com valores que também partem de dentro, do coração e que são capazes de nos impelir a ações que perdurem.

Todos estes tesouros que emanam da dimensão espiritual estão presentes nas diversas religiões e em seus costumes.

Não obstante as diferenças doutrinais e os caminhos espirituais diversos, as religiões convergem em alguns pontos, decisivos para um ethos mundial. [...] Vejamos alguns: a) cuidado com a vida: todas as religiões defendem a vida; [...] b) comportamento ético elementar: todas as religiões apresentam um imperativo categórico: não matar, não mentir, não roubar, não violentar. [...] Esses imperativos, quando traduzidos em nosso dialeto cultural, favorecem uma cultura de veneração, de diálogo, de sinergia, de não violência ativa e de paz; c) a justa medida: as religiões procuram orientar as pessoas pelo caminho da sensatez; [...] d) a centralidade do amor: todas as religiões pregam a incondicionalidade do amor; [...] e) figuras éticas exemplares: as religiões não apresentam apenas máximas e atitudes éticas, mas principalmente figuras históricas concretas, paradigmas vivos; [...] f) definição de um sentido derradeiro: [...] nunca a morte tem a última palavra, mas a vida, sua conservação, sua ressurreição e sua perpetuidade (BOFF, 2010, p. 105-107).

Todos estes apelos éticos presentes nas culturas e tradições religiosas são inspirações que nos impelem a cultivar, em favor de todos, nossa dimensão mais profunda de um sentir e viver espiritualmente. 
Diante de toda a complexidade do universo e das relações da Terra, que, mesmo diversas, são organizadas e que, mesmo externalizando sua beleza e força, têm uma realidade muito mais profunda e espiritual, nos encontramos diante de uma única atitude: o assombro. "Há um princípio unificador de todo esse imenso organismo total” (BOFF, 200o, p. 146). Mais que uma religião, precisamos nos ligar a uma espiritualidade cósmica, para sentir a imensa majestade da vida. Desta "[...] veneração deriva a mística e a ética da responsabilidade” (BOFF, 2000, p. 150). A partir de uma experiência vivencial de encontrar-se no meio do emaranhado da rede da vida, cercado por sua infinita diversidade e sentindo-se um com a Terra, irrompe-se no ser humano esta espiritualidade cósmica, apontando-nos para uma direção segura: “[...] para o mistério da realidade, conhecida racionalmente pela ciência e experimentada emocionalmente pela espiritualidade e pela mística. Tudo converge no nome d'Aquele que é sem nome: Deus" (BOFF, 2000, p. 150-151).

A natureza revela um pouco daquilo que Deus é em plenitude: se Deus é a comunhão em plenitude, a natureza está também organizada numa rede de relações, onde o ser humano depende da Terra e vice-versa e todos dependem de todos.

A natureza íntima de Deus não é solidão, mas comunhão [...]. Porque é comunhão, tudo no universo se manifesta numa rede de relações, a ponto de tudo estar conectado a tudo em todos os momentos e em todas as circunstâncias. Nada existe fora da relação. [...] Abraçando o mundo, estamos abraçando a Deus (BOFF, 2000, p. 195).

Neste contexto e identificação de Deus com o mundo e do mundo com Deus, temos que tomar precauções para não interpretarmos de maneira errada esta identificação. Deus e o mundo não se igualam (não se trata de panteísmo). De Deus emana toda forma de vida e a Ele tudo converge. A natureza, o ser humano e a Terra são criação e manifestação da plenitude da vida, que é o próprio Deus. Ele faz-se presente entre nós em comunhão conosco, mas não se iguala a nós e nem à Terra (panenteísmo). Nele esperamos a plena glorificação e realização da vida (BOFF, 2000, p. 196).

Quando falamos que Deus está em comunhão conosco pela sua criação e que n'Ele tudo será plenamente realizado, falamos numa perspectiva cristã de algo que nem sempre soa bem: morte e, por consequência, ressurreição.

\subsection{Morte e ressurreição na perspectiva ecológica}

O cuidado está também ligado com a morte e a ressurreição. Percebemos isto num exemplo muito simples, de um brinquedo muito famoso nos anos 90: o tamagochi. Ele é uma criação chinesa,

[...] um chaveirinho eletrônico, com três botões abaixo da telinha de cristal, que alberga dentro de si um bichinho de estimação virtual. $\mathrm{O}$ bichinho tem fome, come, dorme, cresce, brinca, chora, fica doente e 
pode morrer. Tudo depende do cuidado que recebe ou não de seu dono ou dona (BOFF, 1999, p. 12).

Este é o ponto-chave que nos dá uma importante lição.

O tamagochi é um brinquedo virtual, mas a Terra é um superorganismo vivo. Assim como o tamagochi, a Terra (e todos os que dela se servem para viver e habitar) precisa de nosso cuidado, já que temos uma faculdade única e poderosa: a inteligência e a consciência. Se não cuidarmos devidamente dela, entrará em risco e poderá morrer. Este mesmo cuidado pelo bicho de estimação virtual que protege, que guarda a vida, que é capaz de curar e até ressuscitar, é o cuidado que deverá ser empregado para com a Terra, os pobres e marginalizados, doentes e esquecidos ou mesmo os animais que nos rodeiam. Este cuidado, consciente e integralmente empregado, pode conferir e devolver vida; pode ressuscitar (BOFF, 1999, p. 13).

Diante da morte, o homem se cala. Ela “[...] é relegada a um problema da subjetividade individual. Cada qual tem de se haver com ela. Ninguém pode ser substituído no seu morrer. Cada um deve-lhe conferir uma significação, ou negar qualquer esperança para além deste mundo" (BOFF, 2000, p. 221). Diante da morte, o ser humano percebe-se num vazio, numa angústia, já que ela significa uma realidade ainda não conhecida. Mas isso depende da significação que a ela damos.

O ser humano é uma complexidade de relações, inserido numa complexidade relacional maior ainda, a Terra. Segundo Boff,

[...] tudo isso ocorre dentro de um imenso processo de evolução. Nesse processo, tudo vem regido pelo equilíbrio entre vida e morte. A morte não vem de fora. Ela se encontra instalada dentro de cada ser. [...] uma vida sem morte é totalmente impensável. A vida é mortal. Sua estrutura é assim organizada, de modo que se vai desgastando, lentamente, até acabar de morrer (BOFF, 2000, p. 222-223).

Quando soubermos integrar a vida e a morte, daremos sentido autêntico a ambas. Se experimentarmos solidão durante a existência, temeremos solidão após a morte; se experimentarmos a comunhão e solidariedade aqui, a morte será uma plenificação, fazendo parte da vida e sem destruí-la.

Nesta perspectiva, o ser humano ao nascer já começa a morrer. Biologicamente, ao nascermos, vamos esmaecendo até terminar de morrer. Porém, quando damos significado à existência terrena, vamos nos completando em nossas relações e crescendo até acabar de nascer. É um processo continuo de tensão entre vida e morte, na busca de realização plena num plano maior que o imanente (BOFF, 200o, p. 226).

Enquanto existente na tensão vida e morte, o ser humano se faz vida na unidade corpo e alma. Sendo corpo, está no mundo; sendo alma, busca algo sempre maior. “Transcender é o que faz a identidade do ser humano enquanto alma. Não é estar fora do mundo. É estar no mundo para além dele. Consiste em abrir sempre uma brecha 
em toda a realidade e ver para além dela" (BOFF, 2000, p. 228). Assim, tudo o que fazemos neste plano existencial deve ser realizado com o olhar voltado para algo sempre maior; nunca para si, mas para os outros. Esta perspectiva, sendo holística, nos abre a um horizonte de esperança e alegria, um horizonte de vida plena.

No evento do declive total das forças, o ser humano não tem corpo e alma separados, mas perfeitamente integrados na totalidade do cosmos. O que se separa na morte são o tempo e a eternidade, mas a pessoa entra na dimensão onde tudo está conectado e interligado, de modo que o morrer é um renascer.

A pessoa, ao nascer, passa por uma perigosa crise. Esgotam-se as possibilidades do seio materno. A criança tem de nascer, senão morre. Deixa tudo atrás de si. Mas entra numa dimensão maior do que aquela que lhe tocava viver no seio da mãe. Ao morrer, de forma semelhante, o ser humano entra numa derradeira crise. Extenuam-se as possibilidades de vida biológica e espaciotemporal. Deixa o conjunto das relações que estabelecia com este mundo, com a sociedade e com a família. Entra num outro tipo de relação, agora com a totalidade (BOFF, 2000, p. 230).

Isto nos impulsiona a, neste plano de existência vivencial, orientar bem nossa vida, dando significações e sentido autênticos, para que quando se esgotarem todas as nossas forças biológicas, a morte não seja encarada como término de tudo, mas como plenificação daquilo que tivermos já construído.

Com razão podemos considerar a morte o verus dies natalis (o verdadeiro dia de Natal) do ser humano. [...] com a morte, o ser humano acaba de nascer. Morrer assim é uma bênção da vida. Não morrer é condenar-se a ter sede sem nunca poder encontrar a água borbulhante, ter fome e jamais poder saciar-se, ser botão e jamais poder desabrochar. Ser botão desabrochado e não poder, nunca mais, amadurecer, perfumar e alegrar todo o universo (BOFF, 2000, p. 231).

Na perspectiva cristã, após a morte, assim como com Cristo, ressuscitamos. Esta ressurreição, de que fala a doutrina cristã, é um fato de plena integração humana. Quando morre, o ser humano já ressuscita, pois muda de plano, é perfeitamente integrado, em si e com o universo, e participa de modo misterioso da vida e existência de Deus. "A ressurreição tira os limites de nosso desejo, realiza-o e lhe confere o modo de plenitude" (BOFF, 2000, p. 253).

Se na ressurreição tudo é plenificado, nosso corpo participa deste processo. Por corpo, Boff entende todo tipo de relação e experiência do ser humano, confrontado com as mais diversas realidades e dimensões da força da vida. $\mathrm{O}$ abraço que damos, o carinho que dispensamos, o cuidado empregado, a compaixão pelo pobre e marginalizado, a atenção ao doente, idoso, as alegrias com as crianças e amigos, o zelo e projetos positivos de amor e cuidado com a Terra, a dedicação e empenho por construir uma realidade sustentável e orgânica, enfim, todo tipo de relação 
estabelecida e mediada pelo nosso corpo no mundo, pela ressurreição é levada à perfeição e plenitude. No evento da morte, e por consequência na ressurreição, o ser humano entende, de fato, qual o sentido da espiritualidade que buscava no plano imanente: a perfeição, chegar a Deus (BOFF, 200o, p. 236-237).

Como se depreende, a ressurreição é um processo que vai ocorrendo ao largo da vida. Vamos lentamente ressuscitando, à medida que lentamente também vamos morrendo. Na morte, a ressurreição explode e implode e permite à vida humana uma realização, impossível se continuasse presa aos limites do aqui e do agora. Não obviamente fora do mundo, mas assumindo o mundo e levando-o para um além onde se dá a comunhão inefável com Aquele que é Vida, e Fonte de toda vida. Destarte, morrer não é caminhar para um fim-limite. É peregrinar para um fim-meta alcançado. Por isso, nós não vivemos para morrer. Morremos para ressuscitar. Para viver mais e melhor (BOFF, 2000, p. 237).

Ao chegar a este patamar, o ser humano encontra o que buscava durante toda a vida; integra-se e entende toda a realidade que neste plano era complexa. $\mathrm{Na}$ dimensão espiritual não existe mais dor nem destruição. Toda conjectura que fazemos e reflexão acerca de uma ecologia sustentável e viva encontrará sua redenção. Na esperança deste dia vindouro, caminhamos ansiosos nas sendas da existência, já construindo o caminho para o Infinito.

[...] cultivar nosso desejo do Infinito, impedindo que ele se identifique com objetos finitos. É meditar, contemplar e amar o Infinito como nosso verdadeiro Objeto do desejo. É acreditar que ao morrer cairemos em seus braços para o abraço sem fim e para a comunhão infinita e eterna. Enfim, é realizar a experiência dos místicos: a vida amada no Amado transformada (BOFF, 2000, p. 153154).

O cuidado concretizado em atitudes dá um colorido diferente á desarmonia por vezes presenciada; é sinal de harmonia buscada, construída e evidenciada. "O cuidado essencial é a ética de um planeta sustentável” (BOFF, 2000, p. 135). Se

quisermos buscar este caminho de sustentabilidade nas relações humanas e ecológicas, ao nos guiarmos pelo cuidado que cura, transforma e renova, o caminho de dor e sofrimento torna-se sinal de um novo nascimento; nascimento de um novo ser humano, orientado por uma experiência existencial autêntica, essencial e integral, vislumbrando já um renovado processo para uma nova era de esperança.

\section{Conclusão}

Estamos ancorados à existência num tempo de mudanças. Hábitos, comportamentos, jeitos, costumes, maneiras de pensar, se organizar, viver, conviver e se expressar mudaram de forma radical nos últimos tempos e se transformam, se complementam a cada instante. Tal mudança acontece também na dimensão 
ambiental e ecológica da realidade. O grande problema é que esta dimensão da mudança não foi positiva, mas em grande parte drasticamente destrutiva. Segundo o autor Leonardo Boff, vivemos atualmente imersos numa crise ético-ambiental; nossa relação com a Terra, Casa comum dos seres vivos, tem-se orientado nos últimos tempos por valores falsos, como o antropocentrismo, a maneira errada de entender a convivialidade, o trabalho, o consumo e a exploração dos recursos da natureza, o que gerou um quadro de decadência com relação à ecologia.

Toda crise, porém, sempre deve tornar-se uma oportunidade de crescimento. Diante das dores, como que de parto, no qual sofre a ecologia e a Terra como a grande geradora da vida, a esperança que nos resta é que despontarão destas dores os raios da vida nova que anuncia um novo recomeço. E tal recomeço está em nossas mãos; os seres humanos que contribuíram para destruir os recursos da Terra são os mesmos que têm a responsabilidade de reconstruí-los e preservá-los.

Este recomeço pode parecer uma utopia e um sonho distante. Mas o ser humano vive de sonhos, e tem força diante das perspectivas traçadas. É um sonho, mas que deve ser construído na vida concreta. A filosofia e a teologia, instrumentos para a razão crítica, reflexiva, criativa e espiritual, têm papel fundamental para orientar um novo sentido, para apontar uma direção certa e autêntica para a construção desta nova era planetária, levando em conta a própria integralidade. Somente o ser humano, a partir de sua existência concreta, pode transformar o meio em que vive, influenciar seu grupo e mobilizar as massas para um novo imperativo ético necessário, o cuidado: cuidado com a Terra, responsabilidade pela vida, em especial onde ela se encontra mais ameaçada, no pobre e excluído, e preocupação com as futuras gerações. O ser humano, orientado por princípios éticos e espiritualidade autêntica, tem por responsabilidade guardar e zelar pelo maior patrimônio da Terra: a vida. Esta deve ser preservada em todas as suas instâncias: no próprio ser humano, nos animais irracionais, nas plantas, nas águas, nos seres minúsculos, nas relações afetivas, políticas, econômicas, culturais e religiosas.

Somente um sentimento profundo é capaz de mover as pessoas. A religião deve servir como um instrumento de amor, misericórdia e compaixão. A mensagem religiosa e as pessoas que a anunciaram são um pano de fundo inspirador para a prática dos valores necessários para uma ecologia sustentável que, ao mesmo tempo em que preserva o essencial, se renova a cada dia.

A convivialidade humana com toda a biodiversidade deve ser reinventada pelo próprio ser humano. É necessário um reencantamento pela natureza, pela Terra, pois, afinal, de sua sobrevivência depende a nossa. Este reencantamento se faz necessário e urgente. Ele deve recomeçar dentro de cada pessoa singularmente. As reflexões e a pesquisa aqui apresentada, traduzidas em ações concretas, são o começo, o despontar de uma nova geração: que se preocupa, defende e, sobretudo, cuida da Terra, Casa Comum, Mãe e Geradora da Vida. 
Boff nos convida com otimismo rumo a uma saída existencial que pode ser dada (e já o está sendo) pelo homem face à realidade da crise ético-ambiental. Ele aposta no homem moderno, especialmente no jovem, que não está mais se fechando em si ou em opiniões tendenciosas, mas a cada dia se abre a novas perspectivas e têm ideias novas, criativas e, se necessário, revolucionárias. É um bom sinal de que a mudança já começa a acontecer, de que os humanos estão se tornando conscientes de que a Terra é nossa Casa e nossa Mãe e precisa de nossa ajuda, carinho e cuidado.

\section{Referências}

ARRUDA, Marcos; BOFF, Leonardo. Globalização: desafios socioeconômicos, éticos e educativos: uma visão a partir do sul. Petrópolis: Vozes, 2000.

BAUMAN, Zygmunt. Ética pós-moderna. Trad. João Rezende Costa. São Paulo: Paulus, 1997.

BIOGRAFIAS Y VIDAS. Edward Wilson. Disponível em: <http://www. biografiasyvidas.com/biografia/w/wilson_edward.htm>. Acesso em 30 mai. 2012.

BENTO XVI. Caritas in Veritate. São Paulo: Paulinas, 2009.

BOFF, Leonardo. A vida para além da morte. Petrópolis: Vozes, 1997.

. A nossa ressurreição na morte. Petrópolis: Vozes, 1996.

. Discurso na ONU: por que a Terra é nossa mãe? Disponível em:

<http://leonardoboff.wordpress.com/2012/o4/22/discurso-no-onupor-que-a-terra-enossa-mae/>. Acesso em: 13 mai. 2012a.

; ELIZONDO, Virgil. Ecologia e pobreza: grito da Terra, grito dos pobres.

Revista Concilium/261. Petrópolis: Vozes, 1995/5.

. Ethos mundial: um consenso mínimo entre os humanos. Rio de Janeiro:

Record, 2010.

. Ética da Vida. 2. ed. Brasília: Letraviva, 2000.

. Ética e moral: a busca dos fundamentos. 2. ed. Petrópolis: Vozes, 2003.

. O preço de não escutar a natureza. A NOTÍCIA, Ed. 25.458, 2011 b.

. Saber cuidar: ética do humano - compaixão pela terra. Petrópolis: Vozes, 1999.

. Sustentabilidade: adjetivo ou adjetivo? A NOTÍCIA, Ed. 25.620, $2011 \mathrm{c}$.

_. Sustentabilidade e cuidado: um caminho a seguir. ANOTÍCIA, Ed. 25.627, $2011 \mathrm{a}$.

Tempos de crise, tempos de cuidado. ANOTÍCIA, Ed. 25.953, $2012 \mathrm{~b}$.

FAENELLO, Anderson Francisco. René Descartes: dúvida como método e certeza como busca. Disponível em:

$<$ http://pt.shvoong.com/humanities/philosophy/180928o-ren\%C3\%A9-descartes d\%C3\%BAvida-comom\%C3\%Agtodo/\#ixzzıwOiK8rEI>. Acesso em: o1 mai. 2012.

GOYA, Will. Resenhas de um clássico. Disponível em: <http://www. 
filosofia.com.br/vi_classic.php?id=18>. Acesso em: 10 março 2012

GUATTARI, Félix. As três ecologias. Campinas: Papirus, 1988.

GUDYNAS, Eduardo. Ecologia social na perspectiva dos pobres. In: BOFF;

ELIZONDO, Virgil. Ecologia e pobreza: grito da Terra, grito dos pobres. Revista

Concilium/261. Petrópolis: Vozes, 1995/5.

HEIDEGGER, Martin. Ser e Tempo. Trad. Marcia Sá Cavalcante Schuback. Petrópolis: Vozes, 1989.

JONAS, Hans. O princípio responsabilidade: Ensaio de uma ética para a civilização tecnológica. Rio de Janeiro: Contraponto ed. PUC Rio, 2006.

PAULO VI. Populorum Progressio. São Paulo: Paulinas, 1967.

SPECULUM. Vitalismo. Disponível em:

$<$ http://www.filoinfo.bemvindo.net/filosofia/modules/lexico/entry.php?entryID=109

7. Acesso em: 02 abr. 2012.

VELÁSQUEZ, Júlia Esquivel. Espiritualidade da Terra. In: BOFF; ELIZONDO, Virgil. Ecologia e pobreza: grito da Terra, grito dos pobres. Revista Concilium/261. Petrópolis: Vozes, 1995/5.

WILSON, Edward. A criação. Trad. Isa Mara Lando. São Paulo: Companhia das Letras, 2008.

Submissão: 26.02.2017 / Aceite: 10.04.2017 